\title{
PENGGUNAAN DIKSI PADA WACANA DISKUSI HAFLAH AKHIRUSSANAH SANTRI PONDOK PESANTREN DARUL ULUM MEDALI SUGIO LAMONGAN
}

\author{
Sadarus Aminun \\ Pendidikan Bahasa dan Sastra Indonesia, Universitas Islam Darul 'Ulum Lamongan \\ Email sadarusaminun@gmail.com
}

\begin{abstract}
Diction with the accuracy and appropriateness of word choices related to meaning, grammatical, social, and standard words. The purpose of this research is to be able to see the types of errors in the use of diction and its factors in the discussion discourse of the third and sixth grade santri end of the Islamic Boarding School Darul Ulum Medal Sugio Lamongan. This research uses descriptive qualitative type method. The data in this study are in the form of errors in using diction in the discussion. The techniques used in this research are observation, listening, and note-taking techniques. The results of this study are in the form of errors in the use of diction, including (a) inaccurate use of words, (b) using words in pairs, (c) using two words, (d) introducing between sentences and words, and (e) eliminating prepositions. These factors include (a) the lack of vocabulary, lack of knowledge of word processing and (c) lack of understanding of the language users' understanding of the meaning of the words they use.
\end{abstract}

Keywords: diction, diction errors, discussion discourse, word choice,

Abstrak : Diksi dikaitkan dengan ketepatan dan kesesuaian pilihan kata terkait makna, gramatikal, sosial, dan kata baku. Tujuan penelitian ini agar dapat mengetahui jenis kesalahan penggunaan diksi dan faktor-faktornya pada wacana diskusi haflah akhirussanah santri kelas tiga dan enam diniyah Pondok Pesantren Darul Ulum Medali Sugio Lamongan. Penelitian ini menggunakan metode jenis deskriptif kualitatif. Data dalam penelitian ini berupa kesalahan penggunaan diksi pada diskusi. Teknik yang digunakan dalam penelitian ini adalah teknik observasi, simak, dan catat. Hasil penelitian ini berupa kesalahan penggunaan diksi, meliputi (a) pemakaian kata tidak tepat, (b) pemakaian kata berpasangan, (c) pemakaian dua kata, (d) penghantar antarkalimat dan kata maka, dan (e) peniadaan preposisi. Faktor-faktor terjadinya kesalahan tersebut, meliputi (a) kurangnya kosa kata, (b) kurangnya pengetahuan tentang proses pembentukan kata dan (c) kekurangpahaman pemakai bahasa terhadap makna kata yang dipakainya.

Kata Kunci: diksi, pilihan kata, kesalahan diksi,wacana diskusi

\section{PENDAHULUAN}

Dalam kehidupan sehari-hari, tentunya kita tidak akan terlepas dari berkomunikasi karena manusia bukanlah makhluk individu, melainkan makhluk sosial yang membutuhkan orang lain, bahkan tidak bisa hidup tanpa orang lain. Untuk berkomunikasi dengan orang lain, kita harus menggunakan kata yang sopan. Misalnya kita memerintah, agar yang kita suruh tidak merasa dirinya disuruh, kita harus menggunakan bahasa yang santun.

Menurut Chaer dan Agustina (dalam Marzuqi,2016:1) Sebagai alat komunikasi dan alat interaksi yang hanya dimiliki manusia, bahasa dapat dikaji secara internal maupun secara eksternal, kajian secara internal, artinya pengkajian itu hanya dilakukan terhadap struktur intern bahasa itu saja, seperti struktur fonologisnya, struktur 
morfologisnya, atau struktur sintaksisnya. Pengkajian secara eksternal tidak hanya menggunakan teori dan prosedur linguistik saja, tetapi juga menggunkan teori dan prosedur disiplin lain berkaitan dengan penggunaan bahasa itu yaitu dngan menggnakan kajian sintaksis.

Sintaksis merupakan salah satu kajian ilmu bahasa yang membicarakan frasa, klausa, dan kalimat. Adapun alat sintaksis yaitu peranti-peranti kalimat yang berperan dalam menentukan makna kalimat itu dan atau memberikan kepada penutur (pendengar/pembaca) tentang bagian makna dari kalimat yang dianggap penting oleh penutur (pembicara/penulis) (Sumadi, 2009:152). Dan adapun fungsi sintaksis menurut Sumadi (2009:22) bahwa fungsi sintaksis adalah keterkaitan struktural antara konstituen satu dengan konstituen yang lain dalam kalimat. Di dalam kenyataan tidak sedikit ditemukan kalimat tidak gramatikal yang disebabkan oleh pemakaian kata secara tidak tepat. Di dalam penyusunan kalimat diperlukan kecermatan dalam memilih kata supaya kalimat yang dihasilkan memenuhi syarat sebagai kalimat yang baik. Bidang pemilihan kata itu disebut juga diksi. Jadi, ini merupakan kesalahan diksi yang meliputi kesalahan kalimat yang disebabkan oleh kesalahan pemakaian kata.

Diksi atau pemilihan kata merupakan aspek penting dalam kejelasan kalimat, karena kata yang tepat akan membantu seseorang mengungkapkan dengan tepat apa yang ingin disampaikannya baik lisan maupun tulisan, jika pilihan kata tidak tepat, selain dapat menyebabkan komunikasi terputus, juga dapat mengganggu kejelasan informai yang disampaikan.

Diksi bisa diartikan sebagai pilihan kata pengarang untuk menggambarkan sebuah cerita. Diksi bukan hanya berarti pilih memilih kata melainkkan dinakan untuk menyatakan gagasan atau menceritakan peistiwa tetapi juga meliputi persoalan gaya bahasa, ungkapan-ungkapan dan ssebagainya. Agar dapat menghasilkan cerita yang menarik melalui pilihan kata maka diksi yang baik harus memenuhi syarat, (1) ketepatan dalam pemilihan kata dalam menyampaikan suatu gagasan (2) seorang pengarang harus mempunyai kemampuan untuk membedakan secara tepat nuansa-nuansa makna sesuai dengan gagasan yang ingin disampaikan dan kemampuan unuk menemukan bentuk yang sesuai dengan situasi dan nilai rasa bagi pembacanya (3) menguasai berbagai macam kosakata dan mampu memanfaatkan kata-kata tersebut menjadi sebuah kalimat yang kelas, efektif dan mudahh dimengerti.

Kosasih (2007:22) yang selalu mengaitkan pilihan kata terhadap makna kata, yaitu, pilihan kata elalu dikaitkan terhadap makna kata, yaitu leksikal dan gramatikal. Leksikal adalah makna suatu kata sebelum mengalami proses perubahan bentuk atau sebelum digunakan dalam kalimat, sedangkan, gramatikal adalah makna suatu kata setelah mengalami proses perubahan bentuk, baik melalui pengimbuhan, pegulangan, ataupun pemajemukan.

Berdasarkan pendapat para ahli di atas, dapat disimpulkan bahwa yang dimaksud dengan diksi adalah kemampuan seseorang dalam mendayagunakan kata dengan tepat dan sesuai. Persoalan diksi selalu dikaitkan dengan ketepatan dan kesesuaian diksi terkait makna, gramatikal, sosial dan kata baku.

Setelah mengetahui berbagai penjelasan yang ada di atas, maka penelitian yang diambil tentang kesalahan penggunaan diksi dari argumen seorang santri kelas tiga dan 
enam diniyah dalam suatu forum diskusi haflah akhirussanah santri Pondok Pesantren Darul Ulum Medali. Berdasarkan pengertian kesalahan penggunaan diksi, di dalam kenyataan tidak sedikit ditemukan kalimat tidak gramatikal yang disebabkan oleh pemakaian kata secara tidak tepat. Dalam penyusunan kalimat diperlukan kecermatan dalam memilih kata supaya kalimat yang menghasilkan memenuhi syarat sebagai kalimat yang baik. Jadi, kesalah diksi ini meliputi kesalahan kalimat yang disebabkan oleh kesalahan pemakaian kata, Agar mampu menyampaikan berbagai gagasan secara memadai, santri kelas tiga dan enam dniyah harus dapat menepatkan suatu kata menjadi kalimat yang baik dan dapat dipahami.

\section{KAJIAN PUSTAKA Hakikat Diksi}

Diksi adalah pilihan kata yang dapat menentukan sebuah kalimat menjadi yang baik dan benar dalam menyampaikan maksud dan tujuan tertentu. Suheni (2009) mengataakan bahwa, diksi merupakan pilihan kata yang tepat dan selaras (dalam penggunaanya) untuk mengungkapkan gagasan sehingga diperoleh efek tertenti (seperti yang diharapkan). Berbeda dengan Putrayasa (2007:7) mengatakan bahwa, pilihan kata berasal dari kata dictionaari (bahasa inggris berupa kata dasarnya dictio) merupakan perihal pemilihan kata atau diksi untuk digunakan dalam sebuah kalimat, cukup banyak pengguna media sosial terdapat banyak pilihan kata tidak memahami kata untuk disampaikan, sehingga kalimat tidak dapat dipahami oleh penerima. Dapat disimpulkan bahwa, diksi sebagai pengguna dalam karangan mengarang dengan kalimat dapat dipahami oleh pembaca maupun penerima dengan baik.

Pemilihan kata yang benar dapat memudahkan pembaca atau pendengar dalam mengungkapkan gagasan atau ide yang hendak diucap atau disampaikan. Pemilihan kata dapat membantu seseorang membuat tulisan yang baik dan benar karena ketepatan kata yang dipilih akan mudah dipahami. Keraf (1999:87) mengatakan bahwa, persoalan ketepatan kata akan menyangkut pula masalah makna dan kosa kata. Kekayaan kosa kata yan dimiliki dapat memungkinkan penulis atau pembicara lebih bebas memilih kata yang lebih tepat mewakili pemikiran. Pemilhan kata atau diksi tidak hanya mempersoalkan ketepatan kata namn juga dilihat dari kondisi baku tidaknya kata yang dipakai berkomunikasi. Setiap pilihan kata memiliki makna yang berbeda dalam setiap bahasa. Pemilihan kata sering bertepatan dengan kata-kata yang mengandung makna. Dapat disimpulkan, bahwa setiap pemilihan kata yang digunakan memiliki makna yang bebeda dalam berbahasa sehingga melakukan komunikasi dengan manusia dapat mengetahui maksud dari tujuan bahasa tersebut.

\section{Kesalahan Diksi}

Di dalam kenyataan tidak sedikit ditemukan kalimat tidak gramatikal yang disebabkan oleh pemakaian kata secara tidak tepat. Di dalam penyusunan kalimat diperlukan kecermatan dalam memilih kata supaya kalimat yang dihaslkan memenuhi syarat sebagai kalimat yaang baik. Bidang pemilihan kata itu disebut juga diksi. Jadi, kesaalahan diksi ini meliputi kesalahan kalimat yang di sebabkan oleh kesaalaahaan pemakaian kata. Berikut dikemukakkan beberapa kesalahan diksi yang belum dibicarakan pada bab terdahulu.

\section{Pemakaian Kata Tidak Tepat}

Ada beberapa kata yang digunakan secara tidak tepat. Kata dari atau daripada sering digunakan secara tidak tepat. Kata daripada sering disamakan makna dan fungsinya dengan kata dari untuk menyatakan makna asal. Kata daripada 
hanya tepat digunakan untuk menyatakan makna perbandingan Sugono (2009:222).

\section{Pemakaian Kata Berpasangan}

Ada sejumlah kata yang pemakaianya bepasangan ( disebut juga konjungsi korelatif), seperti baik... maupun..., bukaan.., melainkan..., tidak.., tetapi.., antara.., dan... sering digunakan secara tidak tepat Sugono (2009: 223).

\section{Pemakaian Dua Kata}

Di dalam kenyataan terdapat pemakaian dua kata yang makna dan fungsinya kurang lebih sama. Pemakaian dua kata secara serempak ini tidak efisien. Kata-kata yang sering dipakai secara serentak itu, bahkan di posisi yang sama, antara lain adalah merupakan, agar supaya. Demi untuk, seperti misalnya, atau daftar nama-nama, Sugono (2009:224).

\section{Penghubung Antarkalimat dan Kata Maka}

Kata maka sering menyertai ungkapan penghubung antarkalimat, seperti sehubungan dengan itu maka, oleh karena itu maka, dengan demiian maka, setelah itu maka, jika demikian maka Lanin (dalam Sugono, 2007).

\section{Peniadaan Preposisi}

Di dalaam kenyataan pemakaian bahasa, orang sering meniadakan unsur preposisi yang menyertai verba. Verba yang disertai preposisi itu kebanyakan berupa verba intransistif Sugono (2009:227).

\section{Faktor Penyebab Kesalahan Diksi}

Kesalaan berbahasa adalah pemakaian bentuk-bentuk tuturan berbagai unit kebahasaan yang meliputi kata, kalimat dan paragraf yang menyimpan dari sistem kaidah bahasa indonsia baku. Kesalahan pemilihan kata juga merupakan satu diantara kesalahan berbahasa.

Sebagai pemakai bahasa, warga negara indonesia sudah sepatutnya dapat menggunakan kosa kata yang dikuasainya dengan tepat, tulisan atau pembicaraan tidak mustahil akan membingungkan pembaca atau pendengarnya. Berikut ini adalah tiga faktor penyebab keslahan diksi.

\section{Kurangnya Kosa Kata}

Orang yang banyak menguasai kosa kata akan lebih mudah memilih katakata yang tepat untuk digunakan dalam menyampaikaan gagasanya. Selain itu orang yang menguasai banyak kosakata tidak akan menerima bahwa kata-kata tersebut mengandung arti yang sama karena bisa menempatkan kata-kata itu dengan cermat sesuai dngan konteksnya. Sebaliknya, orang yang tidak menguasai kosakata akan mengalami kesulitan karena tidak mengetahui ada kata yang lebih tepat dan tidak mengetahui ada perbedaan dari kata-kata bersinonim itu.

\section{Kurangnya Pengetahuan Tentang Proses Pembentukan Kata}

Seseorang yang tidak mengetahui cara atau proses pembentukan kata akan sulit membentuk kalimat yang terdiri dari beberapa kata sehingga dalam penulisan atau penuturanya masih terdapat banyak kesalahan. Proses pembentuan kata dapat diperoleh dengan memahami ejaan yang bahasa Indonesia, fonologi, kata umum dan kata khusus, penggunaan klitika akhiran $\mathrm{ku}$,-mu,-nya maupun penggunaan klitika kata ganti -nya dan penggunaan klitika kah dalam kalimat.

Kekurangpahaman Pemakai Bahasa Terhadap Makna Kata yang Dipakainya

Dalam hal ini, pemakai bahasa kurang mengerti atau bahkan tidak mengerti dengan makna kata yang digunakannya saat berbahasa secara lisan maupun tulisan sehingga kata yang dipilihnya tidak sesuai dengan kaidah yang sebenarnya. Makna kata merupakan hubungan antara bentuk dengan sesuatu yang diwakilinya atau hubungan lambang bunyi dengan sesuatu yang di acunya. Makna kata pada umumnya terbagi atas dua macam yakni makna denotatif dan makna konotatif. Denotatif adalah makna kiasan atau bukan makna sebenarnya. 


\section{Fungsi Diksi}

Di dalam diksi juga mengandung fungsi diantaranya: dengan adanya diksi, maka kata menjadi lebih jelas, sehingga kata tersebut terasa tepat sesuai pada penggunanya. Selain itu, ketepatan pemilihan kata atau (diksi) bertujuan untuk tidak menimbulkan interpretassi ataupun tafsiran yang beda antara penulis dan pembaca. Disamping itu, memiliki tujuan dalam memperindah kalimat, sehingga pengarang dapat membuat cerita tersebut menjadi lebih runtut.

\section{Makna Diksi}

Diksi sebagai media penyampaian makna, maksudnya ialah dalam diksi tersebut dapat dipahami bahwa didalamnya terdapat makna denotatif dan konotatif yang mempunyai hubungan erat dengan pemakaian bahasa, termasuk dalam penciptaan karya sastra (setiawan dan andayani 2019 :14). Selanjutnya adalah makna diksi diantaranya:

\section{Makna Denotatif}

Makna denotatif artinya makna asli, makna sebenarnya, atau makna asal dari sebuah kalimat ataupun kata. Dibawah ini beberapa contoh dari makna denotatif:

- Sari sangat "gemar membaca", jadi, tak heran bila dia pintar serta berpengetahuan luas.

- Ari terlihat senang, mungkin ari sedang mendapatkan "keuntungan yang sangat melimpah".

- Tubuh Heny sangat kurus (yang dimaksud kurus disini bermakna denotatif kondisi tubuhnya lebih kecil dibandingkan ukuran badan normal)

\section{Makna Konotatif}

Makna konotatif, menyatakan makna yang memiliki arti bukan sebenarnya terhadap suatu kalimat ataupun kata. Berikut contohnya:

- Seorang ayah "banting tulang” tanpa kenal lelah, bekerja pagi hingga petang hanya untuk mencukupi kebutuhan keluarganya. ("banting tulang" bermakna bekerja keras).

- Rika salah satu murid "kutu buku", maka tak heran bila dirinya pintar dan memiliki pengetahuan luas. ("kutu buku" Bermakna jika rika gemar membaca buku).

- Tania sangat bahagia, kemungkinan dia saat ini mendapat "durian runtuh". (makna 'durian runtuh" disini ialah tania mendapat keuntungan yang sangat melimpah).

\section{METODE PENELITIAN}

Metode yang digunakan dalam penelitian ini adalah deskriptif jenis kualitatif. Pada penelitian deskriptif terdapat kegiatan penelitian yang dilakukan pada objek tertentu secara jelas dan sistematis, dalam penelitian ini melakukan eksplorasi, menggambarkan tujuan untuk dapat menerangkan dan memprediksi terhadap suatu gejala berlaku atas dasar data yang diperoleh dilapangan. penelitian ini menggunakan deskriptif kualitatif dengan alasan (1) data yang disajikan dalam penelitian berupa kata-kata bukan angka dan (2) objek yang digunakan dalam penelitian ini adalah tindakan yang ditampilkan lewat Kesalah Penggunaan Diksi Pada Diskusi Haflah Akhirussanah Santri Kelas Tiga dan Enam Diniyah Pondok Pesantren Darul Ulum Medali-SugioLamongan".

Data merupakan hasil pencatatan peneliti, baik berupa fakta ataupun angka Arikunto (dalam Mudrikah, 2018:31) data adalah keterangan atau fakta tentang suatu kenyataan yang masih mentah dan belum diolah. Data dalam penelitian ini penggunaan kesalahan diksi, fakator kesalahan diksi, dan jenis kesalahan diksi.

Sumber data dalam penelitian adalah subjek dari mana data dapat diperoleh. Menurut Arikunto (dalam Mudrikah, 2018:13), sumber data penelitian ini adalah santri kelas tiga dan 
enam diniyah Pondok Pesantren Darul Ulum Medali Sugio Lamongan. Penelitian tersebut berlangsung selama 1 bulan dan secara keseluruhan setting yang digunakan adalah di Pondok Pesantren Darul Ulum Medali Sugio Lamongan.

Dalam penelitiaan kualitatif instrumen utamanya adalah peneliti sendiri, namun selanjutnya, setelah focus penelitian menjadi jelas, maka kemungkinan akan dikembangkan intrumen peneliti sederhana yang diharapkan dapat melengkapi data dan membandingkan dengan data yang diperoleh sebelumnya (Sugiyono, 2010:223).

\section{HASIL DAN PEMBAHASAN Kesalahan Penggunaan Diksi}

Kesalahan penggunaan diksi ini meliputi kesalahan kalimat yang disebabkan oleh kesalahan pemakaian kata. Dalam hal berikut ini akan menjelaskan satu persatu beberapa kesalahan diksi yang belum dibicarakan pada bab terdahulu.

\section{Pemakaian Kata Tidak Tepat "dari" dan "daripada"}

Pada penelitian ini ditemukan adanya pemakaian kata tidak tepat dalam dialog santri kelas tiga dan enam diniyah pada diskusi haflah akhirussanah. Adapun percakapan tersebut yaitu pemakaian kata "dari" yang tidak tepat sebagai berikut.

\section{"Sebagian dari santri kalian ajak untuk menata sandal para wali santri". [PKTT]}

Pada data (1) kalimat di atas ditemukan kesalahan pemilihan kata dari yang dilakukan oleh santri kelas tiga dan enam diniyah pada dialog diskusi haflah akhirussanah. Seharusnya kalimat di atas tanpa kata dari karena kata dari digunakan untuk menunjukkan perpindahan atau pengalihan dari suatu tempat. Misalnya, "Kamu dari mana?" dan "Mau ke mana?".

Pemakaian kata tidak tepat merupakan salah satu dari beberapa kesalahan diksi. Sugono (2009:222) berpendapat bahwa ada beberapa kata yang digunakan secara tidak tepat. Kata dari sering digunakan secara tidak tepat. Berdasarkan pendapat tersebut dapat disimpulkan bahwa data (1) tidak seharusnya menggunakan kata dari untuk melengkapi kalimat tersebut.

"Santri daripada perkelas apakah semua mulai hari ini sudah seharusnya menyiapkan penampilan-penampilan atau kreasi-kreasi santri pada perlombaan haflah akhirussanah kang?" [PKTT]

Pada data (2) kalimat di atas ditemukan kesalahan pemilihan kata daripada yang dilakukan oleh santri kelas tiga dan enam diniyah pada dialog diskusi haflah akhirussanah.. Seharusnya data kalimat di atas tanpa kata daripada karena kata daripada digunakan untuk membandingkan dua hal. Misalnya, "Santri itu lebih baik daripada pengurus pondok".

Pemakaian kata tidak tepat merupakan salah satu dari beberapa kesalahan diksi. Sugono (2009:222) berpendapat bahwa ada beberapa kata yang digunakan secara tidak tepat. Kata daripada sering digunakan secara tidak tepat. Kata daripada hanya tepat digunakan untuk menyatakan makna perbandingan. Berdasarkan pendapat tersebut dapat disimpulkan bahwa data (2) tidak seharusnya menggunakan kata daripada karena tidak tepat untuk melengkapi kalimat tersebut.

\footnotetext{
"Untuk itu daripada perwakilan kelas tiga dan enam diniyah tolong disampaikan ke temanteman kalian kelas tiga dan enam diniyah atas tugas tugas yang dibagi agar supaya melaksanakan amanahnya masing-masing" [PKTT]
} 
Pada data (3) kalimat di atas ditemukan kesalahan pemilihan kata daripada yang dilakukan oleh santri kelas tiga dan enam diniyah pada dialog diskusi haflah akhirussanah. Seharusnya tanpa kata daripada karena kata daripada digunakan untuk membandingkan dua hal. Misalnya, "Santri itu lebih baik daripada pengurus pondok".

Pemakaian kata tidak tepat merupakan salah satu dari beberapa kesalahan diksi. Sugono (2009:222) berpendapat bahwa ada beberapa kata yang digunakan secara tidak tepat. Kata daripada sering digunakan secara tidak tepat. Kata daripada hanya tepat digunakan untuk menyatakan makna perbandingan. Berdasarkan pendapat tersebut dapat disimpulkan bahwa data (3) tidak seharusnya menggunakan kata darpada karena tidak tepat untuk melengkapi kalimat tersebut.

\section{Pemakaian Kata Berpasangan}

Pada penelitian ini ditemukan adanya pemakaian kata berpasangan dalam dialog santri kelas tiga dan enam diniyah ketika pada diskusi haflah akhirussanah. Adapun percakapan tersebut yaitu pemakaian kata berpasangan sebagai berikut.

"Baik santri kelas 1,2,4,dan 5 diniyah ataupun santri kelas tiga dan enam diniyah. Bahwa pada malam puncak nanti banyak wali santri kelas tiga dan enam diniyah ke pondok. Jadi Mohon dijaga akhlak dan adabnya ketika berada di sekitar pondok." [PKB]

Data (4) tersebut masuk dalam kesalahan pemakaian kata berpasangan yang dilakukan oleh santri kelas tiga dan enam diniyah pada dialog diskusi haflah akhirussanah. Kesalahan dalam pemilihan kata berpasangan ataupun. Seharusnya data kalimat di atas kata ataupun diganti dengan kata maupun untuk lebih tepatnya agar lebih mudah dipahami. Seperti berikut, "baik santri kelas 1,2,4 dan 5 diniyah maupun santri kelas tiga dan enam diniyah. Bahwa pada malam puncak nanti banyak wali santri kelas tiga dan enam diniyah ke pondok. Jadi Mohon dijaga akhlak dan adabnya ketika berada di sekitar pondok".

Menurut Sugono (2009:223), ada beberapa kata yang pemakainya digunakan secara berpasangan (disebut konjungsi korelatif), seperti baik... maupun..., sering digunakan secara tidak tepat. Bedasarkan pendapat tersebut dapat disimpulkan bahwa data (4) seharusnya menggunakan kata baik untuk mengikut kata maupun.

"Bukan santri kelas tiga dan enam diniyah saja yang sibuk untuk mempersiapkan acara ini tetapi santri lainya juga bisa ikut membantu" [PKB]

Data (5) tersebut masuk dalam kesalahan pemakaian kata berpasangan yang dilakukan oleh santri kelas tiga dan enam diniyah pada dialog diskusi haflah akhirussanaah. Kesaalahan dalam pemilihan kata berpasangan tetapi. seharusnya kata tetapi diganti dengan kata melainkan untuk lebih tepatnya agar lebih mudah dipahami. Seperti berikut, "Bukan santri kelas tiga dan enam diniyah saja yang sibuk untuk mempersiapkan acara ini melainkan santri lainya juga bisa ikut membantu." Menurut Sugono (2009: 223), ada beberapa kata yang pemakainya digunakan secara berpasangan (disebut konjungsi korelatif), seperti bukan... melainkan..., Bedasarkan pendapat tersebut dapat disimpulkan bahwa data (5) seharusnya menggunakan kata bukan untuk mengikut kata melainkan.

"Sebagian santri juga tidak hanya menata sandal saja melainkan sebagian santri juga ada yang menjaga parkir sepeda motor wali santri." [PKB] 
Data (6) tersebut masuk dalam kesalahan pemakaian kata berpasangan yang dilakukan oleh santri kelas tiga dan enam diniyah pada dialog diskusi haflah akhirussanah. Kesalahan dalam pemiihan kata berpasangan melainkan. seharusnya kata melainkan diganti dengan kata tetapi untuk lebih tepatnya agar lebih mudah dipahami. Seperti, "Sebagian santri juga tidak hanya menata sandal saja tetapi sebagian santri juga ada yang menjaga parkir sepeda motor wali santri."

Menurut Sugono (2009: 223), ada beberapa kata yang pemakainya digunakan secara berpasangan (disebut konjungsi korelatif), seperti sebagian...., tetapi,,,,. sering digunakan secara tidak tepat. Bedasarkan pendapat tersebut dapat disimpulkan bahwa data (6) seharusnya menggunakan kata sebagian untuk mengikut kata tetapi.

"Antara santri kelas tiga dengan enam diniyah apakah masih ada yang kurang atau sudah cukup sampai disini untuk persiapan haflah akhirussanah nanti?" [PKB]

Data (7) tersebut masuk dalam kesalahaan pemakaian kata berpasangan yang dilakukan oleh santri kelas tiga dan enam diniyah pada dialog diskusi haflah akhirussanah. Kesalahan dalam pemakaian kata berpasangan dengan. Seharusnya diganti dengan kata dan untuk lebih tepatnya agar lebih mudah dipahami, kalimat yang benar adalah seperti berikut, "Antara santri kelas tiga dan enam diniyah apakah masih ada yang kurang atau sudah cukup sampai disini untuk persiapan haflah akhirussanah nanti?"

Menurut Sugono (2009: 223), ada beberapa kata yang pemakainya digunakan secara berpasangan (disebut konjungsi korelatif), seperti antara..., dan..., sering digunakan secara tidak tepat. Bedasarkan pendapat tersebut dapat disimpulkan bahwa data (7) seharusnya menggunakan kata antara untuk mengikut kata dan.

\section{Pemakaian Dua Kata}

Pada penelitian ini ditemukan adanya pemakaian dua kata dalam percakapan (dialog) santri kelas tiga dan enam diniyah pada diskusi haflah akhirussanah. Adapun percakapan tersebut yaitu pemakaian dua kata sebagai berikut.

"Haflah akhirussanah ini adalah merupakan kewajiban kalian semua kelas tiga dan enam diniyah untuk menatanya atau menyiapkanya" [PDK]

Pada data (8) masuk dalam kesalahan pemakaian dua kata yang dilakukan oleh santri kelas tiga dan enam diniyah pada dialog diskusi haflah akhirussaanah. Kesaahan dalam pemakaian dua kata adalah merupakan. Seharusnya salah satu kata tersebut dihilangkan agar menghasilkan diksi yang tepat, misalnya menghilangkan kata merupakan. Untuk lebih jelasnya agar lebih mudah dipahami, maka kalimat yang digunakan seharusnya seperti berikut, "Haflah akhirussanah ini adalah tugas kalian semua kelas tiga dan enam diniyah untuk menatanya atau menyiapkanya"

Sugono (2009:224) berpendapat bahwa di dalam kenyataan terdapat Pemakaian dua kata yang makna dan fungsinya kurang lebih sama. Pemakaian dua kata secara serempak ini tidak efisien, kata-kata yang sering dipakai secara serentak itu, bahkan pada posisi yang sama, antara lain ialah adalah merupakan. Bedasarkan pendapat tersebut dapat disimpulkan bahwa data (8) seharusnya menghilangkan salah satu kata adalah merupakan, cukup dengan kata adalah untuk melengkapi kalimat ersebut. 
"Iya itu jelas harus dibentuk tugas-tugasnya, agar supaya acara kalian berjalan dengan baik dengan kerja sama kalian" [PDK]

Data (9) masuk dalam kesalahan pemakaian dua kata yang dilakukan oleh santri kelas tiga dan enam diniyah pada dialog diskusi haflah akhirussanah. Kesalahan dalam pemakaian dua kata agar supaya. Seharusnya menggunakan salah satu kata agar dan supaya. Karena agar dan supaya memiliki maksud dan tujuan yang sama. Untuk lebih mudah dipahami, contoh kalimat yang benar adalah seperti berikut, "Iya itu jelas harus dibentuk tugas-tugasnya, agar acara kalian berjalan dengan baik dengan kerja sama kalian".

Sugono (2009:224) berpendapat bahwa di dalam kenyataan terdapat Pemakaian dua kata yang makna dan fungsinya kurang lebih sama. Pemakaian dua kata secara serempak ini tidak efisien, kata-kata yang sering dipakai secara serentak itu, bahkan pada posisi yang sama, antara lain ialah agar supaya. Berdasarkan pendapat tersebut dapat disimpulkan bahwa data (9) seharusnya menghilangkan salah satu kataagar supaya, cukup dengan kata agar untuk melengkapi kalimat ersebut.

"Mulai sekarang kita persiapkan kebutuhan kita demi untuk haflah akhirussanah" [PDK]

Data (10) termasuk dalam kesalahan pemakaian dua kata yang dilakukan oleh santri kelas tiga dan enam diniyah pada dialog diskusi haflah akhirussanah. Kesalahan dalam pemakaian dua kata demi untuk. Seharusnya kata demi untuk cukup digunakan salah satu. Untuk lebih mudah dipahami. Contoh kalimat seperti berikut, "Mulai sekarang kita persiapkan kebutuhan kita demi haflah akhirussanah".

Sugono (2009:224) berpendapat bahwa di dalam kenyataan terdapat
Pemakaian dua kata yang makna dan fungsinya kurang lebih sama. Pemakaian dua kata secara serempak ini tidak efisien, kata-kata yang sering dipakai secara serentak itu, bahkan pada posisi yang sama, antara lain ialah demi untuk. Bedasarkan pendapat tersebut dapat disimpulkan bahwa data (10) seharusnya menghilangkan salah satu kata demi untuk, cukup dengan kata demi untuk melengkapi kalimat ersebut.

\section{Penghubung Antarkalimat dan Kata Maka}

Pada penelitian ini ditemukan adanya penghubung antarkalimat dan kata maka dalam percakapan (dialog) santri kelas tiga dan enam diniyah pada diskusi haflah akhirussanah. Adapun percakapan tersebut yaitu penghubung antarkalimat dan kata maka sebagai berikut:

"Sehubungan dengan itu, maka tolong dipersiapkan dengan semaksimal mungkin." [PKDKM]

Data tersebut termasuk dalam kesalahan penghubung antar kalimat dan kata maka yang dilakukan oleh santri kelas tiga dan enam diniyah dalam dialog diskusi haflah akhirussanah. yaitu, sehubungan dengan itu, maka. Seharusnya bisa dihilangkan salah satu antara sehubungan dengan itu, dan maka, sehingga menghasilkan kalimat yang tepat tanpa menghilangkan maksud yang ingin disampaikan. Agar mudah dipahami dicontohkan pada kalimat berikut, "Sehubungan dengan itu, tolong dipersiapkan dengan semaksimal mungkin".

Menurut Lanin (dalam Sugono, 2007) penghubungan antarkalimat (discourse connective) adalah kata atau ungkapan yang menghubungkan suatu kalimat dengan kalimat lain dalam suatu alenea guna menambah kepaduan wacana. Penghubung antarkalimat 
diletakkan di awal kalimat, tetapi bukan di awal kalimat pertama suatu paragraf dan diikuti dengan tanda koma. Berdasarkan pendapat tersebut dapat disimpulkan bahwa data (13) seharusnya menghilangkan kata maka untuk lebih tepatnya dalam kalimat ersebut.

"Oleh karena itu, maka jangan sampai ada yang tidak berjalan dalam melakukan tugas yang sudah dibentuk atau yang sudah diamanahkan" [PADKM]

Data tersebut masuk dalam kesalahan penghubung antar kalimat dan kata maka yang dilakukan oleh santri kelas tiga dan enam diniyah dalam dialog diskusi haflah akhirussanah. Yaitu, oleh karena itu, maka. Seharusnya antara oleh karena itu, dan maka dapat dihilangkan salah satu untuk menghasilkan kalimat yang baik dan benar tanpa menghilangkan maksud dan tujuan yang ingin disampaikan. Lebih jelasnya contoh pada kalimat berikut, "Oleh karena itu jangan sampai ada yang tidak berjalan dalam melakukan tugas yang sudah dibentuk atau yang sudah diamanahkan".

Menurut Lanin (dalam Sugono, 2007) penghubungan antarkalimat (discourse connective) adalah kata atau ungkapan yang menghubungkan suatu kalimat dengan kalimat lain dalam suatu alenea guna menambah kepaduan wacana. Penghubung antarkalimat diletakkan di awal kalimat, tetapi bukan di awal kalimat pertama suatu paragraf dan diikuti dengan tanda koma. Berdasarkan pendapat tersebut dapat disimpulkan bahwa data tersebut seharusnya menghilangkan kata maka untuk lebih tepatnya dalam kalimat ersebut.

"Dengan demikian, maka cukup sampai disini saja semoga acaranya berjalan dengan lancar tanpa ada halangan suatu apapun." [PADKM]
Data tersebut masuk dalam kesaalahan penghubung antar kalimat dan kata maka yang dilakukan oleh santri kelas tiga dan enam diniyah dalam dialog diskusi haflah akhirussanah. Yaitu, dengan demikian, maka. Seharusnya antara dengan demikian dan maka dapat dihilangkan salah satu untuk menghasilkan kalimat yang baik dan benar tanpa menghilangkan maksud dan tujuan yang ingin disampaikan.

Menurut Lanin (dalam Sugono, 2007) penghubungan antarkalimat (discourse connective) adalah kata atau ungkapan yang menghubungkan suatu kalimat dengan kalimat lain dalam suatu alenea guna menambah kepaduan wacana. Penghubung antarkalimat diletakkan di awal kalimat, tetapi bukan di awal kalimat pertama suatu paragraf dan diikuti dengan tanda koma. Berdasarkan pendapat tersebut dapat disimpulkan bahwa data tersebut seharusnya menghilangkan kata maka untuk lebih tepatnya dalam kalimat tersebut.

\section{Peniadaan Preposisi}

Pada penelitian ini ditemukan adanya peniadaan preposisi dalam percakapan (dialog) santri kelas tiga dan enam diniyah pada diskusi haflah akhirussanah. Adapun percakapan tersebut yaitu mengandung kesalahan peniadaan preposisi sebagai berikut.

\footnotetext{
"Santri kelas tiga dan enam diniyah semuanya insha Allah terdiri 50 santri putra dan 55 santri putri' [PP]
}

Data tersebut masuk dalam kesalahan dalam peniadaan preposisi yang dilakukan oleh santri kelas tiga dan enam diniyah dalam dialog dskusi haflah akhirussanah. Yaitu, terdiri 95 santri seharusnya bisa menjadi kalimat yang benar dengan dilengkapi preposisi. contoh kalimat yang tepat adalah sebagai berikut, "Santri kelas tiga dan enam 
diniyah semuanya insha Allah terdiri atas 50 santri putra dan 55 santri putri.

Menurut Sugono (2009:227) di dalam kenyataan pemakaian bahasa, orang sering tidak menyatakan unsur preposisi yang menyertai verba. Verba yang disertai preposisi itu kebanyakan berupa verba intransitif. Meniadakan unsur preposisi yang menyertai verba. Berdasarkan pendapat tersebut dapat disimpulkan bahwa data (18) seharusnya dilengkapi preposisi kata atas untuk lebih tepatnya dalam kalimat ersebut.

"Ok, terima kasih, akan saya bentuk tugastugasnya, lancar tidaknya acara ini tergantung kalian seperti apa mengemban tugas kalian masing-masing, kalau bisa saling bekerja sama." [PP]

Data tersebut masuk dalam kesalahan dalam peniadaan preposisi yang dilakukan oleh santri kelas tiga dan enam diniyah ddalam dialok diskusi haflah akhirussanah. Yaitu pada kalimat tergantung kalian. Seharusnya bisa menjadi kalimat yang benar dengan dilengkapi preposisi. contoh kalimat yang tepat adalah sebagai berikut, "Ok, terima kasih, akan saya bentuk tugastugasnya, lancar tidaknya acara ini tergantung pada kalian seperti apa mengemban tugas kalian masingmasing, kalau bisa saling bekerja sama" Menurut Sugono (2009:227) di dalam kenyataan pemakaian bahasa, orang sering tidak menyatakan unsur preposisi yang menyertai verba. Verba yang disertai preposisi itu kebanyakan berupa verba intransitif. Meniadakan unsur preposisi yang menyertai verba. Berdasarkan pendapat tersebut dapat disimpulkan bahwa data (19) seharusnya dilengkapi preposisi kata pada untuk lebih tepatnya dalam kalimat ersebut.

"Jumlah semua sudah sesuai absensi di kelas diniyah masing-masing kang. " [PP]
Data tersebut masuk dalam kesalahan dalam peniadaan preposisi yang dilakukan oleh santri kelas tiga dan enam diniyah dalam dialog diskusi haflah akhirussanah. Yaitu kesalahan pada kalimat sudah sesuai absensi Seharusnya bisa menjadi kalimat yang benar dengan dilengkapi preposisi. Contoh kalimat yang tepat adalah sebagai berikut, "Jumlah semua sudah sesuai dengan absensi di kelas diniyah masing-masing kang."

Menurut Sugono (2009:227) di dalam kenyataan pemakaian bahasa, orang sering tidak menyatakan unsur preposisi yang menyertai verba. Verba yang disertai preposisi itu kebanyakan berupa verba intransitif. Meniadakan unsur preposisi yang menyertai verba. Berdasarkan pendapat tersebut dapat disimpulkan bahwa data (20) seharusnya dilengkapi preposisi kata dengan untuk lebih tepatnya dalam kalimat ersebut.

\section{Faktor-Faktor Terjadinya Kesalahan Penggunaan Diksi}

Sebagai pemakai bahasa, warga negara indonesia sudah sepatutnya dapat menggunakan kosa kata yang dikuasainya dengan tepat, tulisan atau pembicaraan tidak mustahil akan membingungkan pembaca atau pendengarnya. Berikut ini adalah tiga faktor penyebab kesalahan diksi.

\section{Kurangnya Kosa Kata}

Pada penelitian ini ditemukan adanya kurangnya kosa kata dalam percakapan (dialog) santri kelas tiga dan enam diniyah pada diskusi haflah akhirussanah. Adapun percakapan tersebut faktor-faktor kurangnya kosa kata sebagai berikut.

"Haflah akhirussanah ini adalah merupakan kewajiban kalian semua kelas tiga dan enam diniyah untuk menatanya atau menyiapkanya." 
Data tersebut masuk dalam faktor kurangnya kosa kata yang dilakukan oleh santri kelas tiga dan enam diniyah dalam dialog diskusi haflah akhirussanah pondok pesantren darul ulum medali. Dikatakan sebagai faktor kurangnya kosa kata karena pada data di atas kata adalah merupakan menunjukkan kata bersinonim atau maknanya hampir sama. Seharusnya salah satu kata tersebut dihilangkan agar menghasilkan kosa kata yang tepat, misalnya menghilangkan kata merupakan. Untuk lebih jelasnya agar lebih mudah dipahami, maka kalimat yang digunakan seharusnya seperti berikut. "Haflah akhirussanah ini adalah tugas kalian semua kelas tiga dan enam diniyah untuk menatanya atau menyiapkanya."

Orang yang banyak menguasai kosa kata akan lebih mudah memilih kata-kata yang tepat untuk digunakan dalam menyampaikaan gagasanya. Selain itu orang yang menguasai banyak kosakata tidak akan menerima bahwa kata-kata tersebut mengandung arti yang sama karena bisa menempatkan katakata itu dengan cermat sesuai dngan konteksnya. Sebaliknya, orang yang tidak menguasai kosakata akan mengalami kesulitan karena tidak mengetahui ada kata yang lebih tepat dan tidak mengetahui ada perbedaan dari kata-kata bersinonim itu. Djiwandono (dalam Susanto 2011: 126) berpendapat bahwa kosakata dartikan sebagai pembendaharaan kata-kata dalam berbagai bentuk yang melipuuti katakata lepas dengan atau tanpa imbuhan dan kata-kata yang merupakan gabungan dari kata-kata yang sama atau berbeeda masing-masing dengan artinya sendiri.

Berdasarkan uraian tersebut dapat disimpulkan bahwa data tersebut seharusnya salah satu kata adalah merupakan dihilangkan, cukup dengan memilih salah satu kata adalah untuk lebih tepatnya.

\section{Kurangnya Pengetahuan Tentang Proses Pembentukan Kata}

Pada penelitian ini ditemukan adanya Kurangnya Pengetahuan Tentang Proses Pembentukan Kata dalam percakapan (dialog) santri kelas tiga dan enam diniyah pada diskusi haflah akhirussanah. Adapun percakapan tersebut mengandung kaidah faktorfaktor Kurangnya Pengetahuan Tentang Proses Pembentukan Kata sebagai berikut.

"Teserah kalian, mau saya yang membentuknya secara acak atau dari pihak kalian sendiri untuk siap melakukan suatu tugasnya."

Data tersebut masuk dalam kurangnya pengetahuan tentang proses pembentukan kata yang dilakukan oleh santri kelas tiga dan enam diniyah dalam dialog diskusi haflah akhirussanah pondok pesantren darul ulum medali. Dikatakan sebagai Kurangnya Pengetahuan Tentang Proses Pembentukan Kata karena pada data di atas kata membentuknya terdapat penambahan prefiks mem- dan satuan kata ganti -nya yang menyatakan kepemilikan yang digabungkan dengan kata dasar bentuk yang mana tidak mengubah arti kata dasar tersebut.

Seseorang yang tidak mengetahui cara atau proses pembentukan kata akan sulit membentuk kalimat yang terdiri dari beberapa kata sehingga dalam penulisan atau penuturanya masih terdapat banyak kesalahan. Proses pembentuan kata dapat diperoleh dengan memahami ejaan bahasa Indonesia, fonologi, kata umum dan kata khusus, penggunaan klitika akhiran -ku,-mu,-nya maupun penggunaan klitika kata ganti -nya dan penggunaan klitika -kah dalam kalimat. Menurut Yendra (2018:128) proses 
pembentukan kata merupakan cara pembentukan kata dengan menghubungkan morfem yang satu dengan yang lainya aatau disebut juga dengan word formation. Berdasarkan uraian tersebut dapat disimpulkan bahwa data tersebut terdapat kata membentunya dari kata dasar bentuk yang mendapatkan penambahan prefiks memdan satuan kata ganti -nya.

\section{Kekurangpahaman Pemakai Bahasa Terhadap Makna Kata yang Dipakainya}

Dalam hal ini, pemakai bahasa kurang mengerti atau bahkan tidak mengerti dengan makna kata yang digunakannya saat berbahasa secara lisan maupun tulisan sehingga kata yang dipilihnya tidak sesuai dengan kaidah yang sebenarnya. Makna kata merupakan hubungan antara bentuk dengan sesuatu yang diwakilinya atau hubungan lambang bunyi dengan sesuatu yang di acunya. Makna kata pada umumnya terbagi atas dua macam yakni makna denotatif dan makna konotatif. Denotatif adalah makna kiasan atau bukan makna sebenarnya.

Dalam data yang diperoleh penulis tidak ditemukan adanya data faktor kekurangpahaman pemakai bahasa terhadap makna kata yang dipakainya. Sehingga penulis tidak memberikan penjelasan dan penganalisisan dalam faktor kekurangpahaman pemakai bahasa terhadap makna kata yang dipakainya.

\section{SIMPULAN DAN SARAN}

\section{Simpulan}

Pada penelitian ini yang berjudul Penggunaan Diksi Pada Diskuli Haflah Akhirussanah Kelas Tiga dan Enam Diniyah Pondok Pesantren Darul Ulum Medali Sugio Lamongan dapat disimpulkan sesuai hasil kajian yang telah dipaparkan tersebut, ditemukan (1) kesalahan penggunaan diksi yang terdiri dari pemakaian kata tidak tepat, pemakaian kata berpasangan, pemakaian dua kata, penghubung antar kalimat dan kata maka, dan peniadaan preposisi, dan (2) faktor-faktor terjadinya kesalahan penggunaan diksi yang terdiri dari kurangnya kosa kata, kurangnya pengetahuan tentang proses pembentukan kata dan kekurang pahaman pemakai bahasa terhadap makna kata yang dipakainya.

\section{Saran}

Penulis menyarankan bagi peneliti selanjutnya yang lebih lanjut. Karena penelitian ini dirasa masih kurang. Penelitian jenis kesalahan penggunaan diksi ini dapat dilakukan dengan penelitian yang lebih luas dan mendalam dengan mengadakan penelitian yang sama dengan objek yang berbeda.

Pembaca hendaknya menjadikan penelitian ini sebagai bahan referensi dan pengetahuan yang nantinya dapat dijadikan sebagai pengajaran tentang penggunaan diksi yang baik dan benar, pengajaran tentang bagaiamana kesalahan penggunaan diksi dalam bertutur harus diterapkan dengan baik.

\section{DAFTAR PUSTAKA}

Chaer, Abdul. 2009. Sintaksis Bahasa Indonesa (pendekatan Proses). Jakarta: Rieneka Cipta.

Djardjowdjojo, Soenjono, 2010. Psikolinguistik (Peengaantar Pemahaman Bahasa Manusia). Jakarta: Yayasan Obor Indonesia.

Finoza Lamuddin. 2010. Komposisi Bahasa Indonesia. Jakarta: penerbit diksi instan mulia

Hidayatullah, Ahmad. 2018. Analisis Kesalahan Diksi Pada karangan 
Siswa Kelas IX Smp Islam Daar El-arqam Tangerang. Bekasi: PGMI, Sekolah Tinggi Islam (SLTA) Bani Saleh.

Kasita, Brigita Swaselia. 2015. Analisis Peggunaan Diksi Pada Karangan Guru-Guru SD Kabupaten Mahakam Ulu Kalimantan Timur. Yogyakarta: Fakulttas Keguruan dan Ilmu Pendidikan Universitas Sanata Dharma.

Ulfa, Gamala. 2013. Kesalahan Penggunaan Diksi Pada Karangan Deskripsi Siswa Kelas VIII Sekolah Menengah Pertama Negeri 10 Tanjung Pinang Tahun Ajaran 2012/213. Tanjungpinang: $\quad$ Fakulttas Keguruan dan Ilmu Pendidikan Universitas $M$ aritim Raja Ali Haji.

Marzuqi, Iib. 2016. Sintaksis (dari teori, pengajaran, hingga penelitian. Sukodadi: CV. Pustaka Ilalang.

Sugono, Dendy. 2009. Mahir Berbahasa Indonesia dengan Benar. Jakarta PT Gramedia Pusraka Utama
Huda, Syihabul. 2018. Estetika Berbahasa. Sukabumi : CV Jejak (Jejak Publiser).

Keraf, Gorys. 2006. Diksi dan Gaya Bahasa. Jakarta: PT Gramedia

Kridalaksana, Harimukti. 2005. Kelas Kata dalam Bahasa Indonesia. Jakarta: PT. Gramedia Pustaka Utama.

Putrayasa, I.B. 2009. Jenis Kalimat dalam Bahasa Indonesia. Bandung: PT Refika Aditama.

Sugono, Dendy. 2009. Mahir Berbahasa Indonesia dengan Benar. Jakarta PT Gramedia Pusraka Utama

Sumadi. 2009. Sintaksis Bahasa Indonesia. Malang: A3 (Asih Asah Asuh).

Yendra. 2018. Mengenal Ilmu Bahasa. Yogyakarta: Deepublish Bekerjasama dengan STKIP PGRI Sumbar Press. 